\title{
ECONOMETRIC ACCEPTANCE OF USE \\ OF CORPORATE SOCIAL RESPONSIBILITY
}

\section{ЕКОНОМЕТРИЧНА ДОЦІЛЬНІСТЬ ВИКОРИСТАННЯ КОРПОРАТИВНОЇ СОЦІАЛЬНОЇ ВІДПОВІДАЛЬНОСТІ}

\section{Berezianko Tamara ${ }^{1}$}

DOI: http://dx.doi.org/10.30525/978-9934-571-28-2_2

\begin{abstract}
There is ongoing polemics in the scientific journals about the level, scale and directions of development of core business structures. The approaches that were realized in this research support the fourth political-economic theory and aimed at regulation of corporate sector activity together with adjusting of society relations. Implementation of the European system of economy should go together with the social responsibility of corporates as key institutional non-formalized component of their activity on the national market to ensure sustainable development that would be acceptable to all parties. The overall strategy in food production can be effective only under condition that the society reaches consensus between multi-facet interests of corporate sector as a producer, expectations coming from the society as well as the state and country border regulations. Purpose. The purpose of this study is to combine and develop the theoretical and methodology basis together with practical recommendations regarding the implementation of institutional instruments of sustainable growth for corporate sector in the format of social state, allowing to contribute to meeting the requirements to align the activities of national entities to European practices. Methodology and methods. Theoretical and methodological groundwork of the study derives from key statements, principles and methods of modern economic, political and institutional theory as well as corporate management theory. The following methods were used in the study: statistical analysis - for definition of econometric parameters, results of activity and corporate sector impact; comparison - for identification of trends and specifics of development of social, corporate and wider soci-
\end{abstract}

${ }^{1}$ Doctor of Economic Sciences, Associate Professor,

Head of the Department of Personnel Management and Labor Economics, National University of Food Technologies, Ukraine 
ety spheres of national and world economy; economic and mathematical forecasting using the game theory to confirm the hypothesises and check the evidential part of the study. Results. The study provides a summary of the nature, policies and the instruments of corporate sector development as part of building of social state and the welfare state using example of EU countries. Based on the conclusions of research we analysed the practice of responsible behaviour of the oligopoly core entities of oil \& fat industry. We developed a methodology and econometric models that were used as a basis for forecasting of consequences of proposed corrections of development of corporates of oil\& fat industry. We proposed an algorithm, the model and practical aspects of implementation of the economic and corporate mediation concept on the level of entity and the industry. The effectiveness of proposed approach is justified by calculations; the study suggests a methodological approach towards implementation of the corporate management theories and is focused at combination, on a mediation basis of the social benefits and national welfare theory by Kaldor-Hiks, of principles of oligopoly entities optimal management by Jean Tirole and J-J. Lafonte and considerations of oligopoly market structure by Cournot. As a result, correct general outcome for optimal regulation and ensuring the Nash equilibrium was reached.

\section{1. Вступ}

Ринкове суспільство особливо в умовах поточної фінансової кризи, знаходиться в пошуку активних засобів впливу на внутрішній та транснаціональний корпоративний сектор. У результуючих документах міжнародної спільноти: формат G-20 - наголос зроблено не тільки на завданнях пом'якшення впливу кризи, але і на реформуванні головних чинників та інструментів регуляції в інституціональному середовищі [1]. Основним інструментом реформування визнано впровадження «економічного соціалізму», реформуванню МВФ та СБ на користь підвищення ролі країн, що розвиваються та реалізації завдання подолання розбіжностей у статках та багатстві між ними та країнами «золотого міліарду ». Європейська спільнота зажадала від власних урядів більш рішучих державних заходів щодо трансграничного регулювання. Сполучені Штати висловили різку незгоду з цього питання і закликали до подолання протекціонізму, колективізму та настроїв поразки ідей ліберальної економіки. 


\section{Berezianko Tamara}

Між тим, оцінювання Світового банку проходять у ракурсі підтримки думки світової спільноти щодо необхідності зниження тиску на бізнес. Це підтверджує тезу щодо конфронтації теоретичного та практичного підходів стосовно регулювання діяльності корпоративного сектору між прихильниками маржиналістської та соціальної концепції, що реалізуються у рамках англо-американської та європейської конструкції партнерства бізнесу та суспільства. В матеріалах Саміту G-20, безпосередньо зазначено: уряди мають розробляти прозоре, справедливе та надійне регулювання бізнесу, включаючи постійний моніторинг та нагляд за його діяльністю [2].

Соціальна відповідальність корпоративного сектору використовується як головна інституціональна неформалізована складова функціонування бізнесу в розвиненому ринковому середовищі. В європейській практиці коригування поведінки та діяльності корпоративного сектору досягається на рівні спільних та національних політик з дуже прискіпливою деталізацію бажаних напрямків впливу в секторах діяльності та галузях господарства.

На рівні світового регулювання наголоси корпоративної відповідальності набули статусу глобальних правил встановлення господарського порядку та перетворено у інструменти забезпечення розвитку у прийнятний для усіх членів суспільства спосіб.

Мета. Метою дослідження є об'єднання та розробка теоретико-методологічних положень та практичних рекомендацій щодо запровадження інституціональних інструментів сталого розвитку корпоративного сектору у форматі соціальної держави.

Завдання. Досягнення поставленої мети зумовило постановку та вирішення наступного завдання: сформулювати методологічний підхід до визначення суспільної корисності діяльності підприємства корпоративного сектора через оцінювання рівня корпоративної соціальної відповідальності.

Методологія. Головним питанням сучасної теорії олігопольного ринку треба визнати формування ефективних засобів регуляції поведінки та стосунків із суспільством провідних олігопольних структур та їх сателітів, стосовно яких ми можемо використати визначення «корпоративний сектор» та «олігопольне ядро». 3 огляду на зазначене особливої уваги потребує можливість застосування державних та суспільних засобів регулювання [3]. Традиційно вплив олігополістичного 
формату ринку розглядався науковцями під кутом зору забезпечення рівних можливостей у конкуренції. Основу теорій недосконалої конкуренції було закладено Е. Чемберліном [4], Дж. Робінсон [5], В. Парето [6], П. Самуельсоном, Дж. Гелбрейтом [7], Г. Штакельберг, Дж. Бейном та С. Фішером [8]. Автори намагались пояснити новий тип ринку, тому особливості монополізму та недосконалої конкуренції було об'єднано, запропоновано будувати теорії рівноваги на основі аналізу монополій, а не вільної конкуренції. 3 метою побудови економіко-математичних моделей стійкості, в рамках інституціонального напрямку (Гэлбрейт Дж., Уильямсон О., Кейвз С, Эрнст Д., ОзаваТ.), розроблялись моделі впливу інститутів на олігополії, глобалісти (Хаймер С, Киндлбергер Ч., Берман Дж., Нейдер Р., Хольман М.) досліджували оцінку впливу міжнародних олігополій на світову економіку та наслідки формування транс-національних монополій. Проте отримано було проміжні результати, які змогли набути статусу теорій реформації ринку.

Нарешті, напередодні розгортанні світової фінансової кризи було започатковано нову економіку (Духроу У., Хінкельмерт Ф., Гросс Д., Стюарт Дж., Белл Д., Бенуа А., Норт Д., Ж. Тіроль), яка обгрунтувала необхідність зміни цілі існування ринку: від придбання та накопичення до розподілу (поширення багатства на все більшу кількість країн та соціальних груп).

Логіка. Що стосується інституціональних можливостей обмеження деструктивної та анти конкурентної поведінки учасників олігопольного ринку це питання недостатньо опрацьоване наукою і потребує дослідження. Хоча, останнім часом стали з'являються дослідження, присвячені опортуністичності поведінки гравців ринку: власників, менеджменту, персоналу (соціуму) та державного управління (деструктивна боротьба еліт).

Ринкове суспільство особливо в умовах зростаючої фінансової кризи, знаходиться в пошуку активних засобів впливу на внутрішній та транснаціональний корпоративний сектор. Призначення таких пошуків - розширення сфери розподілу та співучасті у результатах, приведення діяльності учасників бізнес-середовища до потреб системи цінностей суспільства та розширення можливостей зростання.

Ми вважаємо, що для розгляду специфіки олігопольного ринку в умовах інституціональної теорії достатньо досліджувати поведінку його очільників - олігопольного ядра або корпоративного сектору, яке 


\section{Berezianko Tamara}

по суті $є$ не тільки виразником його інтересів, але і провідним господарюючим об’єктом його структури.

\section{2. Виклад основного матеріалу дослідження}

Світове ринкове співтовариство почало приділяти увагу розвитку процесу зближення інтересів суспільства та корпоративного сектора ще $з$ 90-х років минулого століття.

Олігопольний ринок в пост трансформаційних суспільствах перетворюється у ринок фізичних осіб, що конкурентні відносини перестають такими бути. Отримувати постійний прибуток в рамках олігопольного ринку вдається за рахунок маніпулювання цінами із використанням домовленостей та почергового використання ролі лідера, уникання контролю з боку держави, збереження масштабу прибутків та уявності конкуренції між господарськими одиницями [9].

Олігополісти вдаються до скорочення виробництва, масових звільнень та використовують макроекономічні засоби компенсації та створення надприбутку. Сучасні дослідження визнають найбільшою вадою олігопольного ринку - спроможність блокувати механізми саморегуляції ринку [10].

Євроінтеграційні прагнення України потребують розглядати оцінку впливу олігополій на соціум у контексті бачення Директив, Регламентів та стандартів спільного та галузевого ринків. Центр «Розвиток КСВ» радить проводити оцінку впливу та складання карти стейкхолдерів на основі матриці (рис. ). Означений підхід передбачає визначення груп впливу щоразу при виникненні потреби, зміни ринкової ситуації, розробці нової стратегії або переходу у інші територіальні координати.

Ю.С. Благов, із посиланням на А. Керолла [11] пропонує розширений варіант формування матриці стейкхолдерів [12]. Цей варіант дозволяє повномасштабним чином розглядати ситуацію та визначати способи ії вирішення. Недоліком, на наш погляд можна вважати надмірну комбінаторність, що потребує врахування понад 6500 варіантів розвитку ситуації.

Ми вважаємо за доцільне запропонувати власний підхід до визначення економічної складової матриці впливових груп, врахування інтересів яких забезпечує ефективний розвиток (рис. 1). Узагальнюючи запропоновану матрицю впливу ми можемо умовно представити сферу зацікавлених сторін як триграму пов'язаних стосунків. 
Econometric acceptance of use of corporate social responsibility

\begin{tabular}{|c|c|c|c|}
\hline Суспільний сектор & \multicolumn{2}{|c|}{ Соціальний сектор } & $\begin{array}{c}\text { Корпоративний } \\
\text { сектор }\end{array}$ \\
\hline \multicolumn{4}{|c|}{ Національне суспільство у цілому } \\
\hline \multicolumn{2}{|c|}{ Місцева громада } & $\begin{array}{l}\text { Члени сімей } \\
\text { персоналу }\end{array}$ & $\begin{array}{c}\text { Власники } \\
\text { та інвестори }\end{array}$ \\
\hline Державні установи & Впливові особи & Споживачі & Клієнти-користувачі \\
\hline Органи управління & 3MI & $\begin{array}{c}\text { Громадяни } \\
\text { суспільства } \\
\text { як користувачі } \\
\text { сукупного продукту }\end{array}$ & Постачальники \\
\hline Органи влади & \multirow{3}{*}{$\begin{array}{c}\text { Благодійні } \\
\text { організації, } \\
\text { громадські фонди }\end{array}$} & & Конкуренти \\
\hline Органи контролю & & \multicolumn{2}{|c|}{ Менеджмент } \\
\hline та покарання & & \multicolumn{2}{|c|}{ Працівники } \\
\hline
\end{tabular}

\section{Рис. 1. Схема взасмного впливу учасників в сучасному ринковому суспільстві}

У Давосі на при кінці січня 2011 р. обговорено питання переходу до нової конструкції світового порядку: головними стають завдання збалансування потреб економіки та вимог екології, а також економічного зростання та потреб суспільства. Досягнення поставлених завдань $є$ можливим лише через суспільну регламентацію діяльності корпоративного сектора.

\section{3. Специфіка розвитку корпоративного сектору України}

Сучасна індустрія виробництва харчової продукції країни налічує 21216 підприємств (станом на 01.01.2014 р.) різних форм власності. При цьому підприємства малого формату складають понад 93\%. В структурі корпоративного сектору як ніде інде представлена група середніх підприємств, які складають 26,7\%, у порівнянні: вага середніх підприємств у національному господарств становить 5,7\%, а у промисловості - 10,9\%.

Найбільше прибуткових підприємств зосереджено у виробництві солоду $(83,3 \%)$, тютюнових виробів $(80,0 \%)$, молокопродуктів та морозива (71,8\%), печива (70,9\%), шоколаду та кондитерських виробів (70,2\%), добування солі $(66,7 \%)$, виробництво олії та жирів $(65,8 \%)$, мінеральної та солодкої води $(63,5 \%)$, пива $(63,6 \%)$. Найбільшу кількість збиткових підприємств зосереджено у секторі виробництва спирту етилового (72,4 \%) та макаронних виробів (58,8\%).

Олігопольне ядро секторальних харчових ринків складають:

- у секторі виробництва кондитерської продукції 5 компаній, які сукупно займають $65 \%$ внутрішнього ринку і $40 \%$ кондитерського експорту; 


\section{Berezianko Tamara}

- у секторі імпорту риби та морепродуктів 5 компаній, які контролюють 75\% постачання в Україну;

- у секторі виробництва лікеро-горілчаної продукції ринок контролюють 5 компаній, які займають понад 70\% національного ринку та $54 \%$ експорту;

- у оліє-жировому секторі лідирують 3 компанії, сукупна вага яких перевищує $62 \%$;

- у секторі переробки молока та виробництва сирів -3 компанії, які сукупно контролюють понад 65\% внутрішнього ринку та понад $80 \%$ експорту;

- у секторі виробництва соків ядро складається із 5 компаній іноземного підпорядкування, які займають $90 \%$ ринку соку.

Наведені данні свідчать, що $72 \%$ складу олігопольного ядра харчової промисловості, яке контролює майже $90 \%$ сукупного виробництва, вже не належить національній юрисдикції.

При цьому за українським законодавством [13] монопольним визнається положення, коли контрольована частка ринку перевищує $35 \%$, якщо підприємство не доведе що зазнає сильної конкуренції. Європейське законодавство визнає монопольною консолідовану частку понад $4 \%$.

Нами було виконано пряме вимірювання прямого та похідних економічних ефектів від діяльності олігопольного ядра оліє-жирової промисловості України, як провідної експорто орієнтованої галузі, що займає лідируючи позиції в світі.

В процесі оцінки похідних ефектів було використано ефект мультиплікатора споживання, який демонструє, як витрати одного економічного суб'єкта призводять до доходів і подальших витрат інших економічних агентів.

Аби виміряти похідний ефект у споживчо-соціальній сфері, зміну доходів домогосподарств було скориговано на коефіцієнт-мультиплікатор. Державні витрати розраховують як суму податків, сплачених відповідними компаніями, а також податків, які було сплачено їх агентами.

Для оцінки впливу було обрано заробітну плату у компаніях постачальників, рівень податків, отримані прибутки та розмір обігового капіталу. Для визначення витрат, які відбуваються через придбання імпортних товарів та послуг, частку обігового капіталу було 
помножено на одиницю мінус частка імпорту у внутрішній валовий продукт (ВВП). Оскільки компанії олігопольного ядра мають значний перелік постачальників для аналізу відібрані лише ті підприємства, у обсягах поставки яких компанії олігопольного ядра займають понад $80 \%$.

Здійснення продажу відбувається у рамках встановленої торгівельної націнки 8\%, націнка на продукцію торгівельної мережі складає 20-25\%. Таким чином сукупна дистриб'юторська маржа на продукцію дорівнює 33\%. Використовуючи дані розрахунків було визначено суспільний та сукупний суспільний ефекти від відповідальної діяльності компаній олігопольного ядра галузі. Доброчинну та благодійну діяльність було враховано у підсумковому результаті.

Таблиця 1

Оцінка ефекту від відповідальної діяльності олігопольного ядра оліс-жирової промисловості України, \%

\begin{tabular}{|l|c|c|c|c|}
\hline $\begin{array}{c}\text { Олігопольне } \\
\text { ядро }\end{array}$ & $\begin{array}{c}\text { Соціальний } \\
\text { ефект }\end{array}$ & $\begin{array}{c}\text { Корпоративний } \\
\text { ефект }\end{array}$ & $\begin{array}{c}\text { Суспільний } \\
\text { ефект }\end{array}$ & Усього \\
\hline Кернел & 4,5 & 66,7 & 28,8 & 48,0 \\
\hline ДнОЕ3 & 2,9 & 90,9 & 6,1 & 25,5 \\
\hline Віолія & 3,5 & 72,5 & 23,9 & 26,5 \\
\hline Усього & 3,8 & 74,4 & 21,8 & 100 \\
\hline
\end{tabular}

Відносне співставлення дозволяє наочно впевнитись, що ефекти від діяльності в основному зосереджено в корпоративному секторі, а соціальний ефект виглядає зовсім незначним. Означена економічна ситуація, розвиток національного ринку та євроінтеграційні прагнення спонукають ділове середовище до формалізації цього напрямку.

\section{4. Підходи до формування економетричної моделі оцінки впливу олігополій}

В результаті опрацювання значної кількості варіантів рішень та теорій, нами пропонується методологічний підхід до моделювання задачі щодо регулювання діяльності корпоративного сектору з метою максимізації суспільної та соціальної компоненти.

У якості відправної крапки нами обрано модель Лафонта-Тіроля максимізації суспільних благ в умовах специфіки олігопольного ринку. 


\section{Berezianko Tamara}

При цьому ми свідомо припускаємо наявність зворотного зв'язку між рівнем вироблених суспільно-соціальних благ та існування зусиль корпоративного сектору щодо мінімізації власних витрат. Також враховується той факт, що від держави та соціуму приховується інформація стосовно реальної вартості вироблених послуг та продуктів, що вкладається у основні висновки теорії опортунізму. Загальне моделювання спирається на основні канони теорії контракту і дозволяє розглядати стосунки між основними гравцями як контракт між замовником (соціумом), виконавцем (корпоративним сектором) та регулятором (державою), за обов'язкового врахування діяльності усіх учасників гри у форматі соціальної держави.

Загальна постановка задачі досить добре інтегрується із базовими принципами, викладеними в роботах Ж. Тіроля [14] та Ж.-Ж. Лафонта [15] про оптимальне керування замовленням бізнесу вироблення суспільно корисних благ. В нашому випадку, в категорію таких благ природним чином потрапляє суспільна та соціальна компоненти.

При цьому, теоретична база суттєво вирішує задачу опортуністичності бізнесу та асиметрію інформації: адже мінімізація видатків бізнесу при виробленні таких благ необхідно буде використовувати інформацію, яка буде значною мірою прихована від Регулятора та суспільства. Зокрема справедлива вартість (в тому числі і найманої праці). Для розв'язання, зокрема, пропонується підхід, що переходить від детермінованої до стохастичної моделі максимізації.

При цьому зазначимо, що перехід до динамічної структури є цілком виправданим і більш точно моделює реальний світ, застосований інструментарій включає в себе, зокрема, теорію ланцюгів Маркова.

Змістовним висновком наведених нижче результатів може бути те, що максимізація суспільного та соціального ефекту буде тим краще досягатися, чим меншою є похибка у вимірюванні як цільової змінної, так і прихованої інформації, що активно використовується бізнесом задля мінімізації власних витрат.

В першому випадку практичне вирішення може полягати у дослідженні суспільної користі від діяльності бізнесу: при цьому враховано як монетарні показники (наприклад, сплачені податки, заробітна плата, відрахування на соціальні заходи), так і індексні (наприклад, які вимірюють задоволеність умовами праці, безпека праці, екологічна відповідальність бізнесу тощо). 


\section{Econometric acceptance of use of corporate social responsibility}

У другому випадку, висновок лежить у площині вдосконалення «регулятором» прозорості економічного середовища, створення конкурентних умов та підсилення ролі інформаційно-аналітичної складової національної економічної безпеки. Типовий приклад елементу реалізації подібних завдань - періодичне вимірювання індексу прозорості найбільших публічних компаній Ізраїлю.

Функція корисності для виконавця (олігопольного ядра) буде дорівнювати:

$$
U=t-\psi(e)=t-\psi(\beta-C),
$$

де

$\mathrm{t}$ - вартість трансферу за реалізацію вироблення замовлених благ, вираженого монетарно, від суспільства до бізнесу.

Тоді, соціальне та суспільне благо (ефект) буде мати форму:

$$
S-(1+\lambda)(t+C)+U=S-(1+\lambda)(\beta-e+\psi(e))-\lambda U,
$$

де $\lambda$ - рівень податкового навантаження.

Оптимальне регулювання э результатом максимізації очікуваного суспільного та соціального ефекту від діяльності корпоративного сектору (у нашому випадку олігопольного ядра), за обмежень стимулювання та індивідуальної раціоналістичності, тобто:

$$
\begin{gathered}
\operatorname{Max} \int_{\underline{\beta}}^{\bar{\beta}}(S-(1+\lambda)(\beta-e+\psi(e))-\lambda U) d F(\beta), \\
\dot{U}(\beta)=-\psi^{\prime}(e(\beta)), U(\beta) \geq 0 \text { для будь-якого } \beta
\end{gathered}
$$

В наведених вище умовах, оптимальний контракт суспільства та бізнесу на вироблення суспільних та соціальних благ, є імплементований шляхом набору (меню) правил лінійного (пропорційного) поділу витрат, за яких виконавець обирається шляхом самоселекції. Відповідно випадковість (похибка у вимірювання показників діяльності виконавців), незважаючи на походження, не призводить до втрати корисності, якщо тільки виконавець є нейтральним до ризику.

Зауважимо, що змістовні результати були отримані МакАфі та МакМілланом (1991) та Пікардом та Реєм (1990) для випадку інтерпретації, коли в якості виконавця виступала команда фірм або агентів. Це повністю відповідає поточній конструкції олігополічного ринку, а саме дозволяє використати означене припущення до олігопольного ядра ринку, що досліджується. 
Таблиця 2

Синергія та взаємодія дефініцій «соціальний, суспільний та корпоративні ефект» у процесі моделювання

\begin{tabular}{|c|c|c|c|c|}
\hline $\begin{array}{c}\text { Стратегія/i-та } \\
\text { компанія }\end{array}$ & $\begin{array}{c}\text { Обрання зусиль } \\
\text { протидії } e_{1}^{i}, \text { за } \\
\text { умови інформації } \beta^{i}\end{array}$ & $\begin{array}{c}\text { Обрання зусиль } \\
\text { протидії } e_{2}^{i}, \text { за } \\
\text { умови інформації } \beta^{i}\end{array}$ & $\cdots$ & $\cdots$ \\
\hline $\begin{array}{l}\text { Стратегія/ } \\
\text { Регулятор }\end{array}$ & & & $\cdots$ & $\cdots$ \\
\hline $\begin{array}{l}\text { Обрання } \\
\text { стратегії поділу } \\
\text { витрат за про- } \\
\text { цедурою Р1 }\end{array}$ & $\begin{array}{c}\mathrm{HS}= \\
S-(1+\lambda)(t+C)+U \\
\mathrm{HC}= \\
t-\psi\left(e_{1}^{i}\right)\end{array}$ & $\begin{array}{c}\mathrm{HS}= \\
S-(1+\lambda)(t+C)+U \\
\mathrm{HC}= \\
t-\psi\left(e_{2}^{i}\right)\end{array}$ & $\cdots$ & $\cdots$ \\
\hline $\begin{array}{l}\text { Обрання } \\
\text { стратегії поділу } \\
\text { витрат за про- } \\
\text { цедурою Р2 }\end{array}$ & $\begin{array}{c}\mathrm{HS}= \\
S-(1+\lambda)(t+C)+U \\
\mathrm{HC}= \\
t-\psi\left(e_{1}^{i}\right)\end{array}$ & $\begin{array}{c}\mathrm{HS}= \\
S-(1+\lambda)(t+C)+U \\
\mathrm{HC}= \\
t-\psi\left(e_{2}^{i}\right)\end{array}$ & $\cdots$ & $\cdots$ \\
\hline$\ldots$ & $\cdots$ & $\cdots$ & $\begin{array}{c}\text { крапка } \\
\text { рівноваги } \\
\text { Неша] } \\
\end{array}$ & $\ldots$ \\
\hline$\ldots$ & $\ldots$ & $\ldots$ & $\ldots$ & $\ldots$ \\
\hline
\end{tabular}

- $H S$ - сукупність суспільного та соціального ефекту,

- $H C$ - корпоративний ефект

У випадку, коли імплементація наборів (меню) лінійних контрактів $\epsilon$ можливою для кожної фірми, $C^{i}$ можна замінити на $C^{i}+\sum_{j \neq i} C^{j}, \mathrm{i}$ таке саме розміщення витрат також можливо імплементувати. Насправді, додаток $\sum_{j \neq i} C^{j}$ грає таку саму роль, як і випадкове збурення $\tilde{\varepsilon}$ вище. Оскільки воно $€$ функцією лише від $\beta^{j}, j \neq i$, то в точциі рівноваги гри Неша, то тоді його зміст буде сприйматися фірмою «і» як зовнішній чинник.

На основі наведених вище теоретичних узагальнень, суспільне замовлення певних благ (які б водночас повертали би у вигляді як продукції, так і соціальної складової у вигляді майбутніх індукованих витрат домогосподарств, заробітної платні, похідних бенефітів для держави тощо) буде оптимальним, якщо для їх створення формуються умови, за яких працює метод. Йдеться, насамперед, про створення низки правил поділу видатків між замовником та виконавцем. 
Це фактично слугує фундаментом для обгрунтування корпоративної соціальної відповідальності як інструмента, що забезпечує досягнення рівноважного стану із заданим цільовим розподілом сукупного суспільного ефекту.

Тепер ми можемо перейти до визначення ключових параметрів розширення базової моделі Тіроля-Лафонта.

\section{5. Оцінка суспільного та соціального ефекту діяльності олігопольних компаній}

В межах теорії Тіроля припускається, що в оптимальному розв'язку задачі максимізації суспільної корисності, перед вимаганням певних благ та бенефітів від виконавця - фірми-олігополіста, олігопольного ядра, тощо, держава та соціум повинні інвестувати певний початковий капітал.

В нашому випадку, олігополія, що склалася на ринку, вже функціонує багато років і майже не потребує у явному вигляді дотацій, субсидій чи капітальних інвестицій з боку держави або громади чи суспільства (практично вони були отримані у вигляді пільгових приватизацій, свідомого нерегулювання діяльності, відмови від жорсткого податкового та офшорного контролю). Крім того, деякі суспільні інвестиції було зроблено раніше, зокрема, як: інфраструктура, якою користується олігопольне ядро/компанія-олігополіст; людський капітал, зокрема освіта та відповідна додана вартість; можливість користуватися економічним середовищем, зокрема створення певного клімату, відмінний від інших середовищ сприятливий рівень та структура видатків (наприклад, вартість електроенергії, виробленої на атомних станціях) та інш.

Суспільний та соціальний ефект від корпоративної відповідальності оцінюється як в монетарній формі, так і за допомогою експертних оцінок відповідності потреб суспільства та результатам функціонування бізнесу, що можуть бути спостережними. Це означає, вихідна функція суспільної та соціальної корисності буде отримано як скориговану модель із чисельними та експертними показниками. Моделювання було проведене із відносним рівнем похибки в розмірі 5\%, порядок якої емпірично підтверджується флуктуаціями показників діяльності галузі.

На практиці доцільно проводити зворотне оцінювання та відповідних ваг, обираючи експертну загальну оцінку підприємства та шляхом 


\section{Berezianko Tamara}

регресійного аналізу (наприклад, узагальнених лінійних моделей) оцінювати коригувальні коефіцієнти та ваги.

Так, Перекрестов Д.Г, Поварич І.П., Шебашев В.А [16] пропонують наступний трикроковий підхід. На першому кроці, з урахуванням міжнародних стандартів з соціальної звітності, визначаються основні напрямки («номінації»), зокрема:

- відповідальність перед споживачами;

- розвиток HR, вкладення в людський капітал;

- добросовісна ділова практика;

- корпоративне громадянство;

- екологія і безпека;

- участь в розвитку громадянського суспільства.

На наступному етапі визначаються показники по кожній з «номінацій». Вони формуються в три групи: обсягу (кількості), якості та ефективності КСВ. третьому етапі, кожній з груп показників (обсягу, якості та ефективності КСВ) присвоюється базова сума балів.

Зауважимо, що питання достовірності використаних показників $€$ також актуальним. На це звертають деякі автори, наприклад Тарасова Н.А. [17].

Зворотній зв'язок в рамках досліджуваної моделі дається формою залежності результуючих зусиль бізнесу на мінімізацію власних витрат та вироблених суспільних благ, що на загальному рівні характеризується певним індексом. На практиці такий взаємозв'язок виражено у зростанні продуктивності праці на підприємствах із високим рівнем корпоративної соціальної відповідальності.

Таким чином, задача відшукання точки рівноваги Неша вирішується для гри із трьома учасниками:

- державою (регулятором, основна задача якого - максимізація поточної вартості власного прибутку від функціонування системи замовлення соціально-суспільних благ),

- соціальною компонентою - одним із основних бенефіціарів благ, що виробляються та учасником такого процесу,

- олігопольним ядром (корпоративним сектором або компанією-виконавцем замовлення, основний прибуток якого - поточна вартість грошових потоків, пов'язаних із основним видом діяльності - «носієм» бізнесу (наприклад, конкретна галузь промисловості - у нашу випадку оліє-жирова галузь). 
Загально відомо, що моделі рівноваги Курно є частковими випадками рівноваги за Нешем. Відповідно, дослідження конкурентності для олігополічного середовища 3 необхідністю використовує методи теорії ігор та узагальнення концепції рівноваги.

В основі такого підходу лежить теорема Неша: «В кожній безкоаліційній грі існує хоча б одна ситуація рівноваги (в змішаних стратегіях)».

Як наслідок, отримується рівноважний стан. На підставі отриманих результатів, знов застосовується модіфікована модель Тіроля. Визначений таким чином ітераційний процес збігається до певної точки рівноваги із визначенням оптимальної системи регулювання та асимптотичних параметрів ринку.

Підкреслимо, що в ітераційній стадії переструктуризації олігопольного ринку та оцінки відповідного впливу на параметри моделі, модель Курно може бути замінена на іншу, що більш точно відображає очікування від потенційного застосування моделі.

Моделювання залежності підвищення ефективності праці та чинників, що визначаються індексом зростання ФЗП отримано шляхом застосування скорингової моделі на підставі як даних експертної оцінки рівня факторів, пов'язаних із ефективністю праці та кожному підприємстві

Основні змінні, що входили до моделі є дані про рентабельність, структуру виробництва, ринкову долю кожного підприємства та ступінь пов'язаності із іншими бізнесами (дистриб'юторами та постачальниками), дані чинники, що пов'язані із поточним рівнем продуктивності праці (рівень контрактної культури, понаднормове навантаження, гендерна рівність тощо).

Оцінка шуканих структурних змін в розподілі сукупного суспільного ефекту від відповідальної діяльності отримується шляхом симуляцій структури ринку та змін у продуктивності праці, викликаних підвищенням ФЗП. Одним із ключових припущень буде переважно інтенсивний шлях зростання якості та продуктивності праці.

Синергію розвитку часток по олігопольному ядрі представлено на рис. 2.

До базових припущень відноситься зростання прибутків та обігового капіталу пов'язаних із олігопольним ядром структур (дистриб'юторів та постачальників). Оцінка залежності будується на базі моделі, викладеної вище. Зміни в структурі сукупного суспільного ефекту, за умови впровадження корпоративної соціальної відповідальності оцінено вище. 


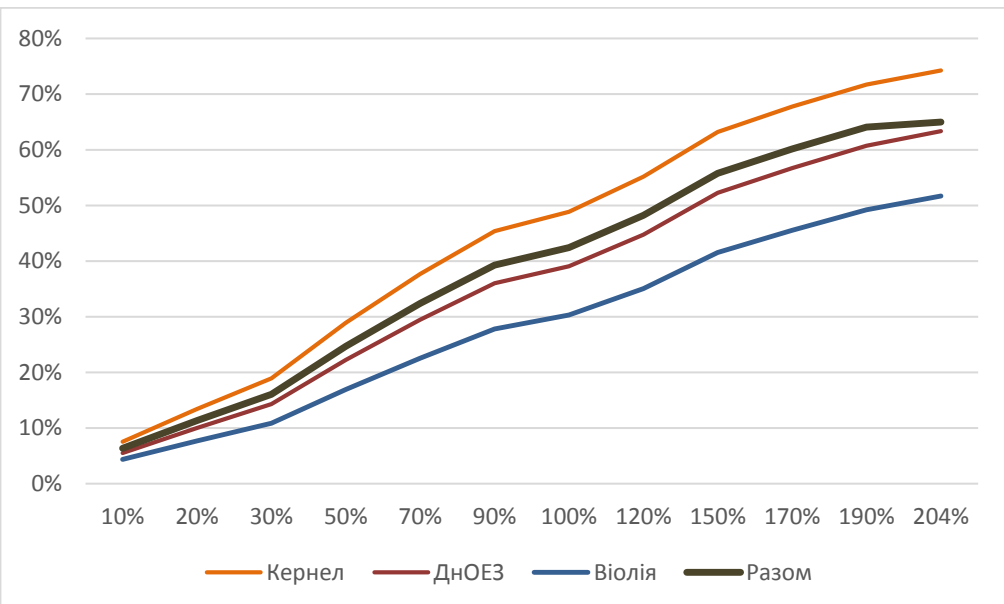

Рис. 2. Графічна інтерпретація сценарію розвитку в олігопольному ядрі при зміні політики соціальної відповідальності

Таблиця 3

Зміни в ланцюжку залежних структур у наслідок підвищення відповідальності олігопольного ядра

\begin{tabular}{|c|c|c|c|c|c|c|}
\hline \multirow[b]{2}{*}{ Компанії } & \multicolumn{2}{|c|}{ Постачальники } & \multicolumn{2}{|c|}{$\begin{array}{l}\text { Дистриб'ютори i } \\
\text { роздрібні торговці }\end{array}$} & \multicolumn{2}{|c|}{$\begin{array}{c}\text { Зростання } \\
\text { корпоративного } \\
\text { ефекту }\end{array}$} \\
\hline & 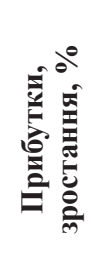 & 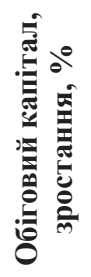 & 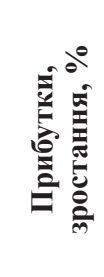 & 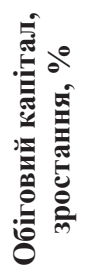 & 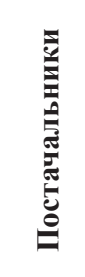 & 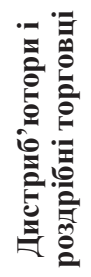 \\
\hline Кернел & 9,5 & 6,0 & 6,0 & 4,4 & 4,58 & 3,13 \\
\hline ДнОЕЗ & 9,0 & 5,0 & 7,0 & 4,3 & 4,03 & 3.54 \\
\hline Віолія & 10,0 & 5,0 & 5,0 & 4,1 & 4,62 & 2,70 \\
\hline Усього & 9,51 & 5,4 & 6,1 & 4,29 & 4,43 & 3,16 \\
\hline
\end{tabular}


Оцінка зростання соціальної складової від корпоративної соціальної відповідальності ядра будується на оцінці коефіцієнту зворотного зв'язку корпоративного та соціального ефекту.

Моделювання проводиться для кожної компоненти суспільного ефекту: витрат домогосподарств, податків тощо. Основними чинниками, що приводить до такого зростання, $є$ зростання прибутковості бізнесу (i, як наслідок, очікуване збільшення бази оподаткування), зростання якості та обсягів реалізованої продукції (зокрема внаслідок ефекту від підвищення продуктивності праці) тощо. Тепер можемо оцінити наслідки підвищення відповідальності комплексно.

Таблиця 4

Очікувані зміни співвідношень у результаті регуляції діяльності олігопольного ядра оліє-жирової галузі,\%

\begin{tabular}{|l|c|c|c|}
\hline Олігопольне ядро & $\begin{array}{c}\text { Соціальний } \\
\text { ефект }\end{array}$ & $\begin{array}{c}\text { Корпоративний } \\
\text { ефект }\end{array}$ & $\begin{array}{c}\text { Суспільний } \\
\text { ефект }\end{array}$ \\
\hline Кернел & 10,0 & 60,9 & 29,1 \\
\hline ДнОЕЗ & 9,4 & 53,0 & 37,6 \\
\hline Віолія & 10,6 & 65,0 & 24,3 \\
\hline Усього & 10,0 & 59,1 & 30,9 \\
\hline
\end{tabular}

Таким чином, зростання за базовим сиенарієм запровадження корпоративної соиіальної відповідальності, щзо приводить до зростання корпоративного ефекту на 3-4\% (в залежності від складової-постачальники або дистриб 'ютори), дає зростання долі сочіальної компоненти до $10 \%$.

\section{6. Висновки}

Проведене моделювання, та розрахунки дозволяють зробити низку пов'язаних висновків: отримано позитивні суспільні, соціальні, галузеві та корпоративні наслідки.

Позитивні суспільні наслідки:

- можна вважати доведеною гіпотезу, що впровадження відповідальної поведінки надає очікуване вирішення проблеми: отримання прибутків корпоративним сектором у соціально виправданий спосіб;

- похідним ефектом від цього суспільство отримує позитивні та суспільні наслідки у вигляді зближення напрямків розвитку та співпадіння інтересів; 


\section{Berezianko Tamara}

- у якості додаткового суспільного ефекту слід очікувати не інфляційного розігріву економіки, відновлення зростання та зниження соціальної напруги у суспільстві;

- проведені розрахунки дозволяють наочно впевнитись, що корпоративний сектор має великий потенціал для делегування та стимуляції росту у соціумі та суспільстві.

Соиіальні ефекти:

- впровадження відповідальної поведінки в олігопольному ядрі галузі забезпечує кумулятивний ефект у пов'язаних структура ланцюжка постачання-дистрибуції із належним отриманням додаткових економічних профітів;

- зростання соціальної компоненти до 10\%, дає додаткове зростання частки корпоративного сектору на 3-4\%;

- підтримка соціального потенціалу дозволяє отримати на місцевому рівні додаткові надходження близько 35\% за рахунок підвищення платоспроможності громади.

Корпоративні ефекти:

- запровадження корпоративної соціальної відповідальності в олігопольному ядрі, що приводить до зростання галузевого корпоративного ефекту на 3-4\% (в залежності від складової - постачальники або дистриб'ютори),

- розігрів соціальної складової корпоративного ядра галузі додатково забезпечує у корпоративному секторі 9,51\% прибутку постачальників; 6,1\% прибутку - дистриб'ютерам; або 4,43\% прибутку - пов'язаних 3 ядром структур корпоративного сектору оліє-жирової галузі у цілому;

- додаткові наслідки корпоративного сектору отримано і в зростання капітальної складової: постачальники отримують зростання на 5,4\%, а дистриб'ютери - на 4,29\%. Задовольняє і той факт, що учасники виробничого ланцюжка мають більш значне зростання обігового капіталу, ніж посередники та торгівля, що слугує забезпеченню розвитку темпів зростання у майбутньому.

Додатково зазначимо, що розрахунками підтверджено не тільки факт можливості використання корпоративної соціальної відповідальності у якості засобу злагоди та відновлення зростання, а і доведено, що використання оцінки корпоративної соціальної відповідальності компаній може слугувати індикатором належного розвитку корпоративного сектору у цілому. 


\section{Econometric acceptance of use of corporate social responsibility}

Ми вважаємо, що впровадження корпоративної соціальної відповідальності у якості галузевого стандарту має значний потенціал забезпечення суспільно адекватного росту бізнесу та ринкової орієнтації суспільства. Потенціал використання КСВ у якості напрямку росту дозволить подолати національній економіці потужну рецесію останніх років, адже нами свідомо було використано в розрахунках лише частину сукупних можливостей, аби забезпечити м'який та поступовий перехід національного бізнесу та системи регуляції у напрямку зближення із засадами європейської системи господарського порядку та соціальної держави.

\section{Список літератури:}

1. Декларация саммита «Группы двадцати» по финансовым рынкам и мировой экономике [Електронний ресурс] - Режим доступу: http://archive.kremlin.ru/events/articles/2008/11/209291/209303.shtml - Перевірено 10.10.2014 р. - доступ до російського ресурсу обмежено згідно із Указом Президента України № 133/2017 від 15.05.2017 р.

2. Содействие более долгосрочному инвестированию институциональными инвесторами: отдельные вопросы и меры политики [Електронний pecypc] - Режим доступу: http://www.oecd.org/daf/fin/private-pensions/ 48616812.pdf - Перевірено 22.02.2018 p.

3. Бенуа А. Де Против либерализма: (к Четвертой политической теории) / Ален де Бенуа : [пер. с фр.;]. - Спб.: Амфора, 2009. - 476 с.

4. Chamberlin Ed. The Theory of Monopolistic Competition. Cambridge / Ed. Chamberlin // Journal Of Business \& Economics Research, Vol. 2, namber 4, pp. 17-26.

5. Robinson J. The Economics of Imperfect Competition. / Joan Robinson London: MacMillan; Reprint edition, 1965. - 132 p.

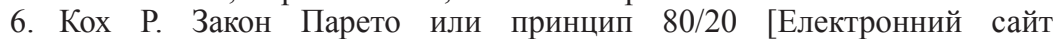
Elitarium] - Режим доступу: http://www.elitarium.ru/2004/07/08/zakon_pareto_ ili_princip_8020.html - Перевірено 05.03.2018

7. Гелбрейт Дж. Новое индустриальное общество: Пер. с англ. / Дж. Гэлбрейт. - М.: ООО «Издательство АСТ»: ООО «Транзиткнига»; СПб.: Terra Fantastica, 2004. - 602 c.

8. Фишер С., Дорнбуш Р., Шмалензи Р. Экономика / С. Фишер, Р. Дорнбуш, Р. Шмалензи: Пер. с англ. со 2-го изд. - М.: Дело, 1999. - С. 231.

9. Казанцева Е.Г. Олигополистические рынки в современной экономике/ Е.Г. Казанцева/Автореферат дис.докт.экон.наук, Томск, 2013. - 40 с.

10. Ietto-Gillies Gr. Transnational Corporations and International Production. L.: Edward Elgar, 2005. P. 88.

11. Carroll A. B. 1999. Corporate social responsibility: Evolution of definitional construct. Business and Society 38 (3): 268-295.

12. Благов Ю.Е. Концепция корпоративной социальной отвественности и стратегическое управление / Ю.Е. Благов // Российский журнал менеджмента, 2004, № 3. - C. 17-34. 


\section{Berezianko Tamara}

13. Про захист економічної конкуренції. - Закон України від 11.01.2001 p. № 2210-III - [Електроний ресурс]. - Режим доступу: http://zakon.rada.gov.ua/ laws/show/2210-14 - Перевірено 05.03.2018.

14. Laffont J.-J., Tirole J. (1993) A Theory of Incentives in Procurement and Regulation - Cambridge: The MIT Press, 1993 - 705 p.

15. Gasmi F., Kennet D. M., Laffont J.-J., Sharkey W. W. (2002) Cost Proxy Models and Telecommunications Policy. A New Empirical Approach to RegulationCambridge: The MIT Press, $2002-274 \mathrm{p}$.

16. Перекрестов Д.Г., Поварич И.П., Шебашев В.А. Корпоративная социальная тветственность: вопросы теории и практики / Д.Г. Перекрестов, И.П. Поварич, В.А. Шебашев - М.: Академия Естествознания, 2011. - 437 с.

17. Тарасова Н.А. Достоверность социально-экономических показателей: семиотический поход / Н.А. Тарасова - М. ; СПб. : Нестор-История, 2012. $288 \mathrm{c}$.

\section{References:}

1. Deklaratsyia sammyta "Hruppy dvadtsaty" po fynansovym rynkam y myrovoi ekonomyke [Declaration of the Group of Twenty's Summit on Financial Markets and the World Economy]. Rezhym dostupu: http://archive.kremlin.ru/ events/articles/2008/11/209291/209303.shtml - Perevireno 10.10.2014 r. dostup do rosiiskoho resursu obmezheno zghidno iz Ukazom Prezydenta Ukrainy № 133/2017 vid 15.05.2017 r.

2. Sodeistvye bolee dolhosrochnomu ynvestyrovanyiu ynstytutsyonalnymy ynvestoramy: otdelnye voprosy y mery polytyky [Promoting a long-term investing by institutional investors: separate issues and policies]. Rezhym dostupu: http://www.oecd.org/daf/fin/private-pensions/48616812.pdf - Perevireno 22.02.2018 r.

3. Benua A. (2009). De Protyv lyberalyzma: (k Chetvertoi polytycheskoi teoryy) [Against Liberalism (Towards the Fourth Political Theory)]. Alen de Benua, Spb.: Amfora, $476 \mathrm{p}$.

4. Chamberlin Ed. The Theory of Monopolistic Competition. Cambridge. Journal Of Business \& Economics Research, Vol. 2, namber 4, pp. 17-26.

5. Robinson J. (1965). The Economics of Imperfect Competition. London: MacMillan; Reprint edition, $132 \mathrm{p}$.

6. Kokh R. Zakon Pareto yly pryntsyp 80/20 [Pareto's Law or The 80/20 Principle] [Elektronnyi sait Elitarium] - Rezhym dostupu: http://www.elitarium.ru/ 2004/07/08/zakon pareto ili princip 8020.html - Perevireno 05.03.2018

7. Helbreit Dzh. (200̄4). Novoe yndustryalnoe obshchestvo: Per. s anhl. M.: OOO "Yzdatelstvo AST": OOO "Tranzytknyha"; SPb.: Terra Fantastica, 602 p.

8. Fysher S., Dornbush R., Shmalenzy R. (1999). Ekonomyka [Economy] Per. s anhl. so 2-ho yzd. M.: Delo, 231 p.

9. Kazantseva E.H. (2013). Olyhopolystycheskye rynky v sovremennoi ekonomyke [Oligopolistic markets in the modern economy] Avtoreferat dys. dokt. ekon. nauk, Tomsk, $40 \mathrm{p}$.

10. Ietto-Gillies Gr. (2005). Transnational Corporations and International Production. L.: Edward Elgar, 88 p. 
11. Carroll A. B. (1999). Corporate social responsibility: Evolution of definitional construct. Business and Society 38 (3): 268-295.

12. Blahov Yu.E. (2004). Kontseptsyia korporatyvnoi sotsyalnoi otvestvennosty y stratehycheskoe upravlenye [Corporate social responsibility concept and strategic management]. Rossyiskyi zhurnal menedzhmenta, № 3, p. 17-34.

13. Pro zakhyst ekonomichnoi konkurentsii. [On Protection of Economic Competition] Zakon Ukrainy vid 11.01.2001 r. № 2210-III. Rezhym dostupu: http://zakon.rada.gov.ua/laws/show/2210-14-Perevireno 05.03.2018

14. Laffont J.-J., Tirole J. (1993). A Theory of Incentives in Procurement and Regulation - Cambridge: The MIT Press, $705 \mathrm{p}$.

15. Gasmi F., Kennet D. M., Laffont J.-J., Sharkey W. W. (2002). Cost Proxy Models and Telecommunications Policy. A New Empirical Approach to RegulationCambridge: The MIT Press, $274 \mathrm{p}$.

16. Perekrestov D.H., Povarych Y.P., Shebashev V.A. (2011). Korporatyvnaia sotsyalnaia tvetstvennost: voprosy teoryy i praktyky [Corporate social responsibility: issues of theory and practice]. M.: Akademyia Estestvoznanyia, 437 p.

17. Tarasova N.A. (2012). Dostovernost sotsyalno-эkonomycheskykh pokazatelei: semyotycheskyi pokhod [Reliability of socio-economic indicators: semiotic approach]. M.; SPb.: Nestor-Ystoryia, 288 p. 